\title{
Kentiçi Otobüs Sisteminin Güvenilirliğini Etkileyen Faktörlerin İncelenmesi
}

\section{Investigation of the Factors Affecting the Reliability of Urban Bus System}

\author{
S. Pelin Çalışkanelli ${ }^{*} \oplus$, Mustafa Özuysal ${ }^{2}(\mathbb{0}$ \\ ${ }^{1}$ Dokuz Eylül Üniversitesi, Mühendislik Fakültesi, İnşaat Mühendisliği Bölümü, 35390, İzmir, TÜRKIYE \\ 2 Dokuz Eylül Üniversitesi, Mühendislik Fakültesi, İnşaat Mühendisliği Bölümü, 35390, İzmir, TÜRKIYE \\ Sorumlu Yazar / Corresponding Author*: pelin.caliskanelli@deu.edu.tr
}

Geliş Tarihi / Received: 08.01.2018

DOI:10.21205/deufmd.2019216125

Kabul Tarihi / Accepted: 21.06 .2018

Araștirma Makalesi/Research Article

Atıf șekli/ How to cite: CALIŞKANELLI, S.P., ÖZUYSAL, M.(2019). Kentiçi Otobüs Sisteminin Güvenilirliğini Etkileyen Faktörlerin İncelenmesi. DEUFMD, 21(61), 259-269.

Öz

Gelişmekte olan şehirlerdeki artan nüfus ve araç sahipliği değerleri göz önüne alındığında insanlara yaşanabilir bir şehir sağlayabilmek için, hızla yükselen özel taşıt talebine cevap vermek yerine, sürdürülebilir altyapı yatırımlarıyla yüksek kapasite sağlayan toplu ulaşım sistemlerinin maksimum verimlilikle kullanılması sağlanmalıdır. Çoğunlukla toplu ulaşımda en büyük payı alan ve özel taşıt trafiğiyle bir arada işletilen kent içi otobüs sistemleri, mevcut yol ve trafik koşullarından etkilenmekte ve verimliliğinin değerlendirilmesi, büyük ölçüde yolculuk sürelerinin analizinden geçmektedir. Son yıllarda önceden belirlenen bir çizelgelemeye bağlılık düzeyi olarak tanımlanan "güvenilirlik" ulaşım sistemlerinin performansının değerlendirilmesinde sıklıkla kullanılmaktadır. Bu çalıșmada İzmir'den seçilen bazı otobüs hatlarına ait güvenilirlik değerleri hesaplanarak, güvenilirliğin trafik akım koşullarından ne düzeyde etkilendiği incelenmiștir. Seçilen hatların kullandığı arterler üzerinde trafik gözlemleri yapılmıș ve hatların geçtiği ana arterlerin Aimsun 6.1 programı kullanılarak benzetimleri yapılmıştır. Sonuç olarak akım hızının ve hattın geçtiği güzergâhtaki şerit sayısının artmasının güvenilirliği arttırdığı, durakta duran otobüs sayısının artması durumunda ise güvenilirliğin olumsuz etkilendiği belirlenmiştir.

Anahtar Kelimeler: Güvenilirlik, Toplu Taşıma, Trafik Akımı, Benzetim, Regresyon Analizi

\section{Abstract}

To ensure sustainable development in cities, the maximum efficiency in the use of public transportation systems should be provided by using sustainable infrastructure investments providing high capacity, instead of supplying the rapidly rising private vehicle based demand. Urban bus systems which mostly take the maximum share in public transportation and are operated under mixed traffic conditions, are highly affected the road and traffic conditions traveled along with them. In recent years, "Reliability" which is defined as the ability of depending on a schedule or headways and a constant travel time, is often used in assessing the performance of transport systems. In this study, the reliability values of some bus lines selected from İzmir were calculated and the effect of traffic flow conditions on reliability is investigated. Traffic observations were made on the arterials used by the selected lines and simulations were made by using Aimsun 6.1. As a result, it is determined 
that the reliability increases when the flow speed and number of lanes increases, and decreases in the case that the number of buses stopping at a certain bus station increases.

Keywords: Reliability, Public Transport, Traffic Flow, Simulation, Regression Analysis

\section{Giriş}

Gelișmekte olan ülkelerin çoğunda özel taşıt kullanımı hızla yükselmekte ve toplu ulaşımda ise en büyük payı lastik tekerlekli toplu ulaşım sistemleri almaktadır. Genellikle özel taşıt trafiği ile bir arada işletilen lastik tekerlekli toplu ulaşım araçları mevcut yol ve trafik koşullarından yoğun olarak etkilenmekte ve bu durum, toplu ulaşım sisteminin performansını etkileyerek hem işletmeci hem de yolcular açısından önemli bir problem oluşturmaktadır.

Bir toplu taşıma sisteminin performansını arttırabilmek için süreklilik ve zamanlama açısından güvenilirliğin sağlanması ayrıca başlangıç-bitiş durakları arasında her sefer için sabit bir yolculuk süresinin yakalanabilmesi hedeflenmektedir [1]. Kentiçi otobüs sistemlerinin performansını sayısal olarak ifade etmeyi sağlayan en önemli ölçütlerden biri güvenilirliktir.

Güvenilirlik, önceden belirlenmiș olan bir çizelgeye bağlılık olarak açıklanabilir. Toplu ulaşım sistemlerinde güvenilirlik, yolcular ve işletmeciler açısından oldukça önemli bir yere sahip olup işletme ölçütü olarak dikkate alınmaması yolcular için bekleme sürelerinin artışına ve düzensiz araç sıklıkları nedeniyle konforsuzluğa neden olmaktadır. Yapılan çalışmalar güvenilirliğin yolcuların tür ve güzergâh seçimleri üzerinde de etkili olduğunu ortaya koymuștur [2, 3]. Ayrıca işletmecilerin güvenilirliği gözetici önlemler yerine daha yüksek hizmet düzeyi için sefer sıklığını arttırması halinde, ișletmeciler açısından maliyet artışına ve filodan yararlanma oranının azalmasına yol açmaktadır [4].

Toplu ulaşım servislerinin güvenilirliği durağa ve hatta bağlı olarak iki ayrı grupta incelenebilmektedir. Durak bazında yapılan detaylandırılmış güvenilirlik ölçütleri, hat ve yol șebekesi bazındaki bütünleșik ölçütlere de dönüştürülebilmektedir [5]. Hat bazlı güvenilirlik, bir otobüs işletmesinin güvenilirlik performansını hat seviyesinde dikkate almaktadır ve belirlenen özel bir hat için ya da tüm sistem için ölçümler de yapılabilmektedir. Durak bazlı güvenilirlikte ise bir otobüs ișletmesinin güvenilirlik performansı seçilen duraklar için değerlendirilmektedir. Güvenilirlik ölçümleri literatürde çeşitli hat karakteristikleri kullanılarak yapılmaktadır. Sefer süreleri [6], kalkış saatlerine bağlılık [7], duraktaki yolcuların bekleme süreleri [2], uygun olmayan kapasite nedeniyle sonraki otobüsü bekleyen yolcu oranı [7] vb. bu hat karakteristiklerine örnek olarak verilebilir. Güvenilirlik ölçütlerinden, anlaşılması ve yorumlanması en kolay ölçüt türü, durak bazlı ve yolculuk süresine dayalı ölçütlerdir [4]. Yolculuk süresi güvenilirliği belirli zaman aralığında seçilen hatların yolculuk sürelerindeki değișimi inceleyerek elde edilebilmektedir.

Lastik tekerlekli toplu ulașımda güvenilirliği etkileyen faktörler genel olarak dört ana grupta toplanabilir. Bunlar; işletmeci, karayolu trafiği, hat ve yolcu karakteristikleri olarak gruplandırılabilir. Şehiriçi trafiğinde tüm taşıtlar ile bir arada işletilmekte olan lastik tekerlekli toplu ulaşım araçları için güvenilirlik hesaplamalarında mevcut yol ve trafik koșullarından kaynaklanacak etkenlerin göz ardı edilmesi mümkün değildir. Bu sebeple, trafikteki araç kompozisyonu, șerit sayısı, trafik talebi ve yönlerinin gün içerisindeki değişimi gibi trafik akımı ile ilgili birçok etken otobüs hatlarının güvenilirliğini etkilemektedir. Bunların dıșında kavşak tipleri, kavşaklarda otobüs öncelikli sistemlerin bulunup bulunmaması, yol kenarı parklanmaları ve otobüs cebi uygulamaları gibi birçok trafik yönetimi ile ilgili faktör de yine güvenilirlik üzerinde önemli oranda etkiye sahiptir [8].

Zirve ve zirve dıșı saatlerde trafiğin farklı özelliklerine bağlı olarak yolculuk süresinde önemli değișikler gözlenebilmekte; bunun sonucunda ise özellikle ilk duraktan uzaklaştıkça durakların ve buna bağlı olarak otobüs hatlarının güvenilirlikleri düșmektedir. Trafik akımının otobüs sisteminin sefer süreleri üzerindeki etkisinin bilinmesi durumunda özellikle otobüs öncelikli güzergâhların belirlenmesinde, zirve saatlerindeki sefer çizelgelerinin oluşturulmasında ve yeni hat planlaması gibi durumlarda daha doğru kararlar alınabilmektedir. Bu çalıșma ile bir otobüs 
hattının, yolcular ve işletmeciler bakımından en önemli performans ölçütlerinden biri olan güvenilirliğinin trafik ve yol geometrisine bağlı hangi parametrelerden etkilendiğinin incelenmesi amaçlanmıştır. $\mathrm{Bu}$ parametreler ortaya konulduğunda, otobüs güzergâhlarında planlanan değișiklikler, güzergâh hizmete alınmadan önce güvenilirlik bakımından sinanabilecektir.

Çalışmada ilk olarak, seçilen analiz bölgesinde hizmet veren otobüs hatlarının geçtiği ana arterlerin benzetim modelleri AIMSUN programı kullanılarak oluşturulmuş ve gözlem noktalarından elde edilen trafik sayımları ile bu modeller çalıştırılmıştır. Ardından akıllı kart verilerinden yararlanılarak belirlenmiș olan otobüs hatlarının durak bazlı güvenilirlikleri hesaplanmıștır. Elde edilen veriler çoklu regresyon yöntemi ile incelenmiș ve otobüslerin güvenilirliğini etkileyen parametreler belirlenmeye çalıșılmıștır. Çalışmanın aşamaları Şekil 1'de özetlenmiştir.

\section{Analiz Bölgesi ve Trafik Gözlemleri}

Çalıșma için seçilen alan, İzmir kent merkezinin büyük bir kısmı ve kentin kuzey bölümünü içermektedir. Analiz bölgesinde organize sanayi bölgesi, çeşitli yoğunluklarda konut alanları, merkezi çalıșma alanları ve ticaret tesisleri gibi farklı arazi kullanım dokuları bulunmaktadır. Analiz bölgesi sınırları içerisinde toplam 60 adet otobüs hattı bulunmakta, bunlardan $45^{\prime} \mathrm{i}$ analiz bölgesi sınırları içerisinde başlayıp yine analiz bölgesi sınırları içerisinde sonlanmaktadır. Bahsi geçen bu hatların bir kısmı kent merkezine bağlantı sağlarken, bir kısmı analiz bölgesi içerisindeki yerleşimlerin farklı ulaşım türlerine (vapur, banliyö ve metro) olan bağlantısını sağlamaktadır.

Analiz bölgesi içinde yer alan hatların önemli bir kısmı Anadolu Caddesi, Altınyol, Cemal Gürsel Caddesi gibi günün her saatinde yüksek trafik yüküne sahip olan farklı arterleri kullanmakta, hatların yolculuk süreleri bu arterlerdeki geometri ve trafik yükü sebebiyle değişkenlik gösterebilmektedir.

Çalışma kapsamında analiz bölgesi içinde bulunan 48 noktada trafik gözlem ve sayımları gerçekleștirilmiștir (Şekil 2). Gözlemler sabah ve akşam zirve saatlerinde 07:00-09:00, 17:0019:00) ve gündüz 12:00-14:00 saatleri arasında video kameralar yardımıyla yapılmıștır. Araç kompozisyonunun sağlıklı bir șekilde tespit edilebilmesi için gerektiğinde gözlem yapılan her yön için birden fazla kamera kullanılması yoluna gidilmiştir. Trafik hacimleri, sayım yapılan güzergâhlar üzerinde şehir merkezine doğru olan trafik akımı ve șehrin dıș çeperlerine doğru olan trafik akımları olarak ikiye ayrılarak çıkartılmıștır.

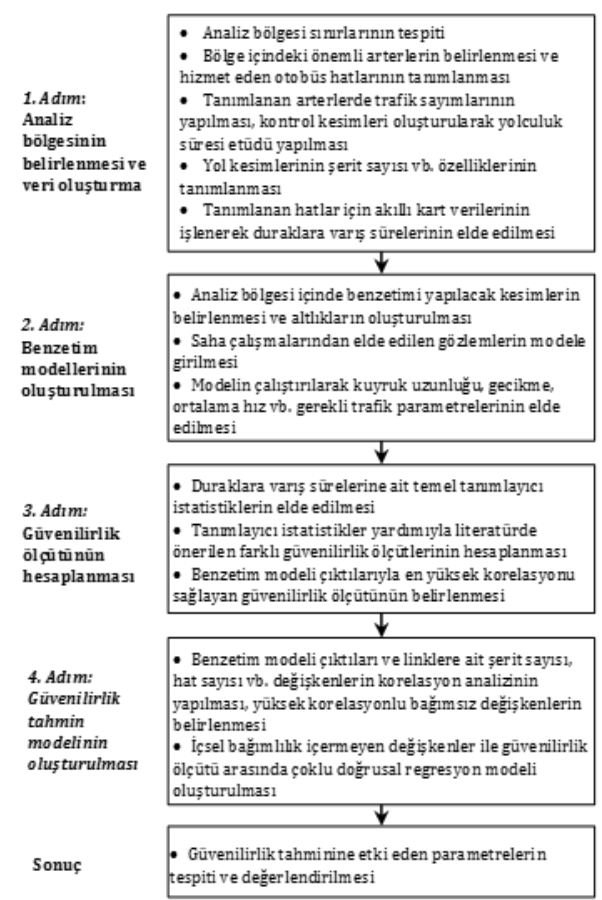

Şekil 1. Çalıșmanın aşamaları

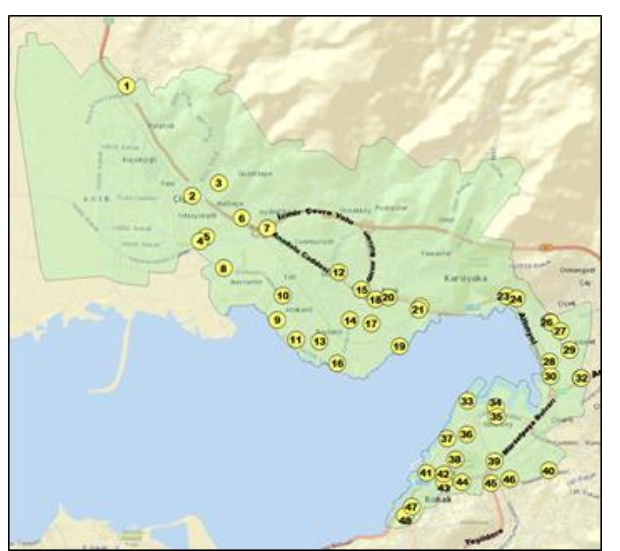

Şekil 2. Analiz bölgesinde trafik sayımı yapılan noktalar

Video kamera ile yapılan çekimler yardımıyla trafik hacmi ile taşıt kompozisyonu belirlenmiştir. Sayımlarda otomobil, minibüs, kamyonet, otobüs ve kamyon olmak üzere 5 farklı araç tipi göz önüne alınmıştır. Sayım 
yönleri ve taşıt tiplerine göre saatlik hacim değerlerinin sabah zirve saatteki dağılımı Șekil 3 ve Şekil 4'te görülmektedir. Şekillerde otomobil haricindeki araç türleri, daha net bir anlaşılabilirlik elde etmek için toplanarak "ağır araç" șeklinde gösterilmiștir.

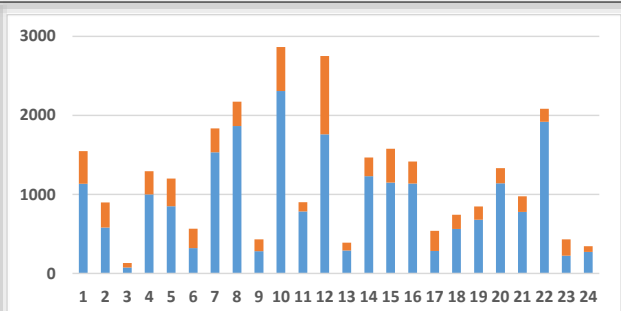

a) Karşıyaka kesimi (kuzey) gözlem noktaları

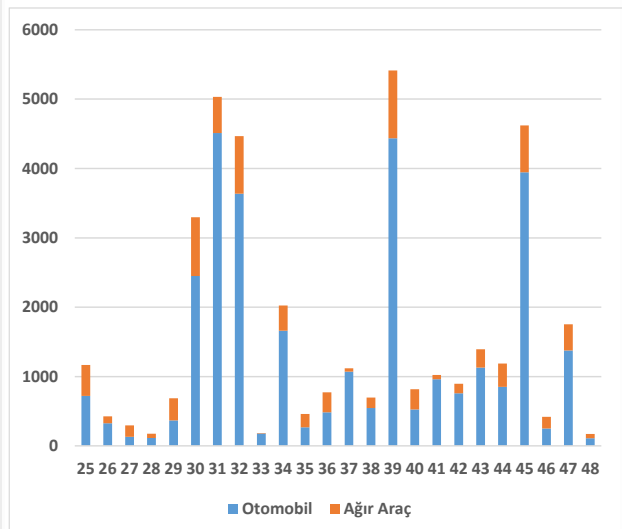

b) Kent merkezi (güney) gözlem noktaları

Şekil 3. Kent merkezi yönünde yapılan trafik hacim sayımları ve araç kompozisyonu

Şekil 3 ve 4 incelendiğinde, kent merkezindeki gözlem noktalarının Karşıyaka'daki (kuzey) gözlem noktalarına göre çoğunlukla daha yüksek trafik hacim değerlerine sahip olduğu görülmektedir. Sabah saatlerinde merkez yönünde yapılan sayımlarda ağır araç oranı çoğunlukla daha yüksektir. Sabah saatlerinde kent merkezi yönünde hareket eden otobüs ve minibüs sayılarının iş ve okul amaçlı yolculuklar sebebiyle arttığı söylenebilir.

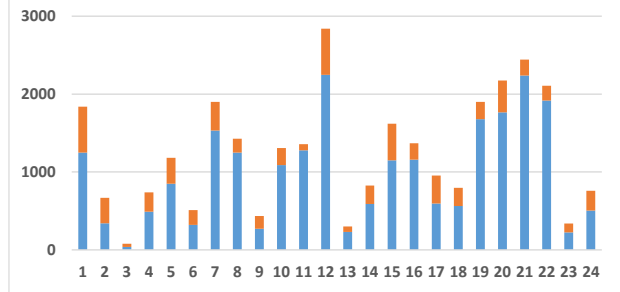

a) Karşıyaka kesimi (kuzey) gözlem noktaları

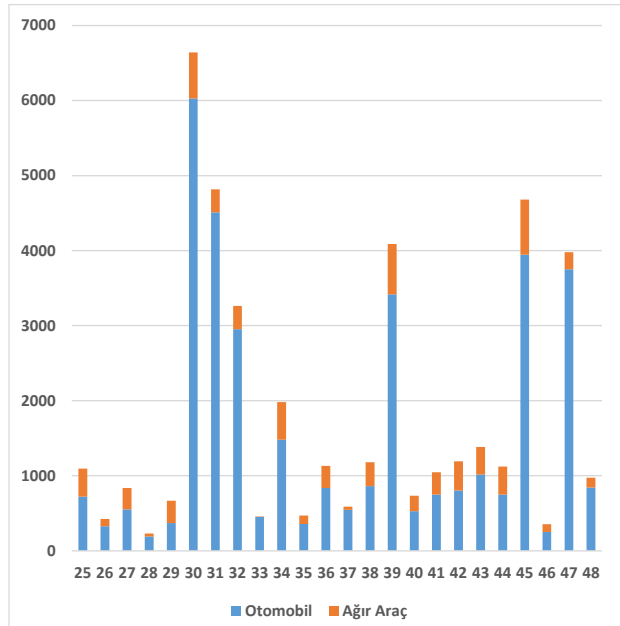

b) Kent merkezi (güney) gözlem noktaları

Şekil 4. Kent merkezinden dış çeperlere yapılan trafik hacim sayımları ve araç kompozisyonu

Kentin kuzeybatı kesiminde bulunan sayım noktaları șehrin dıș çeperinde yer almaktadır. Bu sebeple daha düşük hacim değerlerine sahiptir. $30,31,32,39$ ve 45 numaralı gözlem noktaları kentin en yoğun arterleri üzerinde yer almaktadır, farklı yönlere giden birçok güzergahın ortak kullandı̆̆ı arter üzerinde hem merkeze hem de merkez dışına doğru yüksek hacim değerleri gözlemlenmiștir. Bu gözlem noktalarının kent içi hız yolları üzerinde yer alması ve özellikle Altınyol kesiminin (30-32) kuzey-güney geçişinde kent merkezinden geçen tek alternatif olarak darboğaz oluşturması, bu durumun bașlica sebepleridir. 7, 12 ve 22 numaralı gözlem noktaları, İzmir'in en büyük ilçelerinden olan Karşıyaka İlçesi ve çevresinde yer alan ilçelerin kent merkezine erişimini sağlayan en önemli arter olan Anadolu Caddesi üzerinde yer almaktadır. Bu yüzden her iki yönde yüksek hacimde trafik yükü almaktadır.

Özellikle 12 no.lu gözlem noktasında kent merkezine doğru hareket eden ağır araç oranının yüksek olması, Anadolu Caddesi'nin toplu 
ulaşımda da önemli bir paya sahip olduğunu göstermektedir.

Gözlem noktalarında yapılan sayımlar "TS 6407 Şehir içi ulaşım hesaplamalarında, araç tiplerine göre kullanılacak oto birim katsayıları" numara ve isimli Türk Standardı uyarınca eșdeğer otomobil birimine dönüştürülerek kullanılmıștır [9]. Söz konusu standarda göre şehir içi yollarda minibüsler için 1.15, kamyonlar için 2.0 ve otobüsler için 3.0 eşdeğer otomobil birimi kullanılmaktadır.

\section{Benzetim Modeli}

Çalıșma kapsamında trafik akımından kaynaklanan güvenilirlik kayıplarını inceleyebilmek amaciyla Aimsun 6.1 benzetim programı kullanılmıştır. Aimsun, geniş çalışma alanları için çeşitli araç tipleri, yol geometrisi, kavşak tipleri ve sürücü özelliklerine ait çok detaylı veri girişine olanak veren bir benzetim programıdır. Yolculuk talebinin modellenmesi, statik ve dinamik trafik atamalarının mezoskopik ve mikroskobik benzetim yöntemleri ile incelenmesi gibi birçok çalışma alanında kullanılmaktadır [10]. Trafik mühendisliği çalışmalarında veri toplama sürecinin oldukça uzun, zahmetli ve maliyetli bir süreç olması sebebiyle benzetim programlarından sıklıkla yararlanılmaktadır $[11,12,13,14]$. Ayrica benzetim programları gözlemler sırasında tespit edilmesi güç durumlar ve geniş bir trafik hacim aralığı içinde araştırmacılara çıkarım yapma imkânı sunmaktadır. Çalışmada analiz bölgesi 4 ayrı kesime ayrılarak (Karşıyaka Bölgesi, MontröLozan Bölgesi, Konak Bölgesi ve Altınyol Bölgesi) mikroskobik benzetim modelleri kurulmuştur.

2. Bölümde açılklanan gözlem noktalarından elde edilen sayım değerleri benzetim modelleri için girdi olarak kullanılmış ve çalışma kapsamında yer alan hatların geçtiği güzergahlar mümkün olduğunca yol ağına dahil edilmeye çalışılmıştır. Modelleri oluşturulan 4 bölgeye ait benzetim programı görüntüleri Şekil 5'te verilmiştir. Şekillerde mavi çizgiyle işaretlenen yol kesimleri, benzetim modelinin doğrulanması amacıyla yolculuk süresi gözlemi yapılan kontrol kesimlerini göstermektedir.

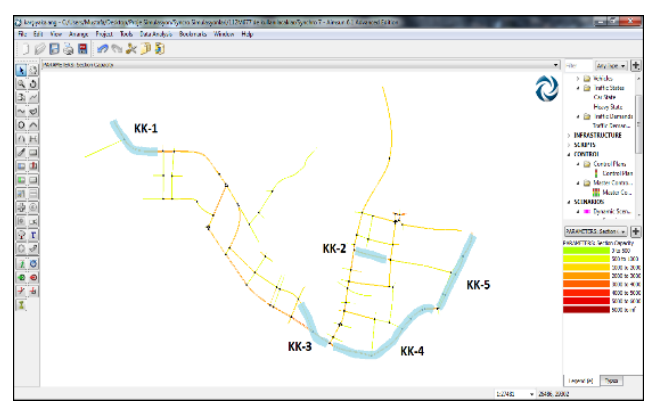

a) Karşıyaka bölgesi

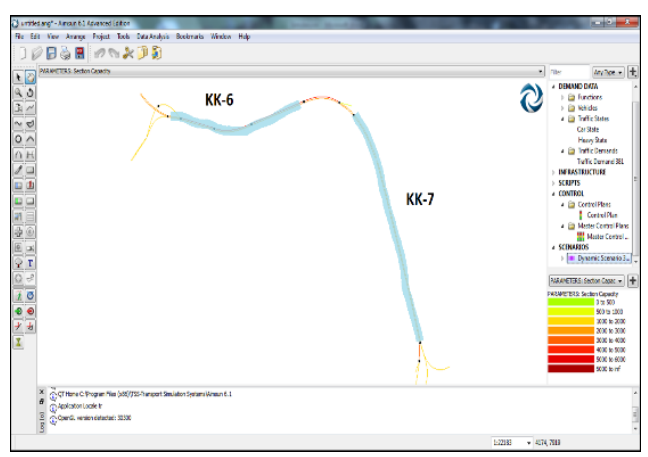

b) Altınyol bölgesi

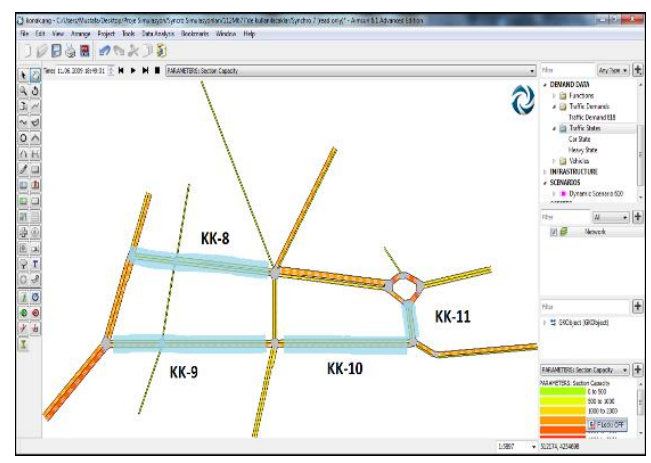

c) Konak bölgesi

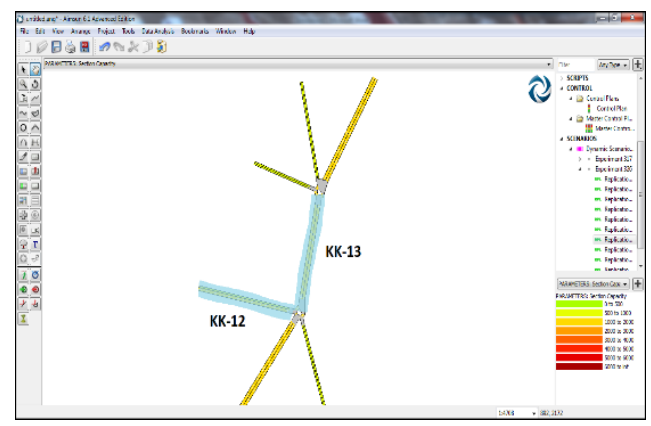

d) Alsancak bölgesi

Şekil 5. Benzetim programı görüntüleri ve kontrol kesimleri 
Benzetim programları ile ilgili en önemli husus benzetimi yapılan sistemin gerçek gözlem alanını temsil edilebilirliğinin araştırıldığı iteratif olarak yürütülen kalibrasyon ve doğrulama (validasyon) sürecidir [15]. Benzetim çalışmalarında, gözlem değerlerine yakın sonuçlar elde etmek için araç olarak kullanılan parametre kalibrasyon değişkeni olarak adlandırılırken, yaklașılmaya çalıșılan gözlem değerlerine de doğrulama (validasyon) değişkeni denilmektedir.

Benzetim modellerinin doğrulanması için örnek olarak seçilen kontrol kesimleri üzerinde bașlangıç ve bitiș noktaları arasındaki yol kesimleri ve kavşakları da içeren yolculuk süreleri kullanılmıștır. Yolculuk süreleri TÜBITAK projesi kapsamında, 13 farklı kontrol kesimi üzerinde, GPS donanımlı (konum ve zaman verisi kaydeden) araç içi kameraya sahip araçla yapılan yolculukların kamera ve GPS kayıtları analiz edilerek elde edilmiştir.

Benzetim çalışmaları sırasında model yolculuk sürelerinin, gözlemlenen yolculuk sürelerine yaklaştırmak (kalibre etmek) amacıyla sinyalize kavşaklar için sürücü reaksiyon süreleri kalibrasyon parametresi olarak seçilmiștir. Aimsun 6.1'de sinyalize kavşaklardaki sürücü reaksiyon süreleri için 1.35 saniye değeri kullanılmaktadır.

Kalibrasyon çalıșmaları sırasında bu değer üzerinde çeșitli varyasyonlar denenmiş, ayrıca literatürdeki sinyalize kavşaklarda sürücü davranıșlarını inceleyen çalıșmalar da dikkate alınmıştır [16, 17, 18, 19]. Tanyel ve ark. [20] tarafından önerilen ve çok sayıda sinyalize kavşakta sınanmış olan reaksiyon süresi değerlerinin yapılan denemeler içerisinde en iyi sonuç veren değerler olduğu belirlenmiștir. Sonuç olarak reaksiyon süresi değerinin ilk sırada bekleyen araç sürücüleri için 1.40 saniye, kuyrukta bekleyen diğer araç sürücüleri için ise 1.22 saniye olarak alınması doğrulama için uygun bulunmuştur.

Benzetim çalışmalarında modellenecek zaman periyodu modele özgü olmakla birlikte genellikle sabah ya da akşam zirve saat süreleri kullanılmaktadır. Bu çalıșma kapsamında birer saatlik zirve saat periyotları kullanılmıştır. Ayrıca benzetimi yaplan sistemin uygun sonuçlar verebilmesi için analiz periyodundan önce şebekeye trafik yüklenmesi gerekmektedir. $\mathrm{Bu}$ amaçla sisteme ek ısınma süresi eklenmeli ya da bir başlangıç durum matrisi tanımlanmalıdır. Bu çalışma kapsamında sisteme ek ısınma süresi (warm-up time) eklenmiștir. Isınma süresi olarak kesin kabul edilen bir değer olmamakla birlikte 15 dakika ila 30 dakikalık süreçler önerilmektedir. $\mathrm{Bu}$ çalıșma kapsamında 15 dakikalık ısınma süresi kullanılmıștır [21]. Aimsun araç ve sürücüye bağlı olarak küçük değişiklikler uygulayarak stokastik yaklaşım ile her tekrar için belli oranda farklı sonuç üretmektedir. Tekrar sayısı için belirlenmiş kesin bir değer olmamakla birlikte sonuçlar normal dağılıma yaklaştırılmaya çalıșllır ve en az 10 tekrar çalıştırılması önerilir [21]. Aimsun birer saatlik dilimler halinde 10'ar tekrar çalıștırılmıș ve ortalamaları alınarak sonuçlar elde edilmiştir.

Kalibrasyon sonucunda kontrol kesimlerinde gözlemlenen yolculuk süreleri ile benzetim programından çekilen yolculuk süreleri arasındaki ilișki Sekil 6'da verilmiștir. Sekilden de görüldüğü gibi, gözlem ve model süreleri ilișkisi, 0.713 düzeyinde bir regresyon katsayısı ile örtüşmektedir. Bu boyuttaki bir benzetim modeli için makul bir doğrulama elde edildiği söylenebilir.

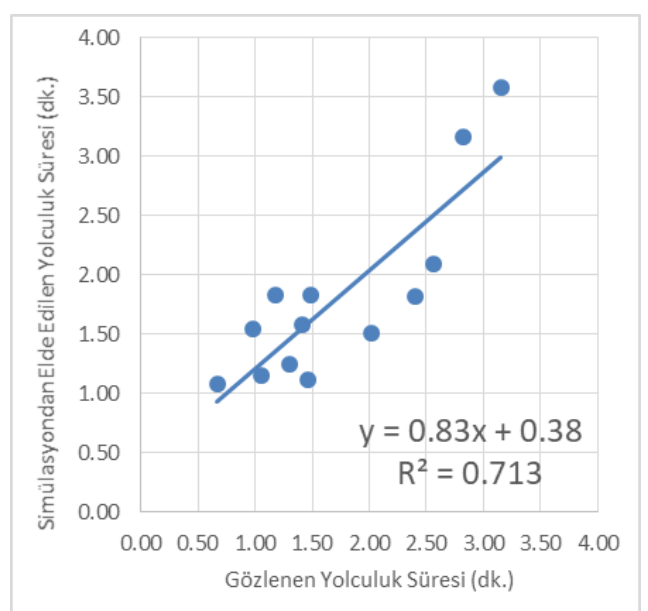

Şekil 6. Kalibrasyon sonucu gözlemlenen ve modellenen yolculuk süreleri

Benzetim modellerinden, sisteme girilen tüm linkler için hareket yönüne bağlı olarak link bazında, șerit sayısı, ortalama gecikme, ortalama hız, trafik hacmi, ortalama yolculuk süresi ve ortalama kuyruk uzunluğu değerleri elde edilmiștir. Programdan elde edilen verilerin bir kısmına ait örnek tablo Tablo 1'de verilmiştir.

Çalışmanın bir sonraki aşamasında Aimsun'dan elde edilen trafik akım parametreleri ile linkler üzerinde bulunan durakların güvenilirlikleri ilișkilendirilmeye çalıșılmıștır. $\mathrm{Bu}$ amaçla 
DEU FMD 21(61), 259-269, 2019

öncelikle her bir link üzerinde bulunan durakların yerleri ve duraklardan geçen hatlar belirlenmiş; daha sonra her bir durağa ait ortalama güvenilirlik değerleri hesaplanmıștır. Durakların hangi link üzerinde olduklarını ve güvenilirlik değerlerini gösteren verilere ait örnek bir tablo Tablo 2'de verilmiștir.

Tablo 1. Benzetim programından elde edilen verilerden bir örnek

\begin{tabular}{ccccccc}
\hline $\begin{array}{c}\text { Link No/ } \\
\text { Yön }\end{array}$ & $\begin{array}{c}\text { Şerit } \\
\text { Sayısı }\end{array}$ & $\begin{array}{c}\text { Ort } \\
\text { Gecikme } \\
\text { (sn/taşıt) }\end{array}$ & $\begin{array}{c}\text { Ort Hız } \\
\text { (km/saat) }\end{array}$ & $\begin{array}{c}\text { Trafik Hacmi } \\
\text { (taşıtt/saat/ } \\
\text { yön) }\end{array}$ & $\begin{array}{c}\text { Ort } \\
\text { Seyahat } \\
\text { Süresi } \\
\text { (dak) }\end{array}$ & $\begin{array}{c}\text { Ort } \\
\text { Kuyruk } \\
\text { Uzunluğu } \\
\text { (m) }\end{array}$ \\
\hline $9 / 1$ & 2 & 16.7 & 36.5 & 804 & 1.0 & 31.9 \\
$9 / 2$ & 1 & 13.0 & 39.0 & 1590 & 1.1 & 31.6 \\
$11 / 1$ & 2 & 7.3 & 25.0 & 215 & 0.3 & 5.1 \\
$12 / 2$ & 2 & 30.6 & 17.0 & 324 & 0.5 & 45.3 \\
$13 / 1$ & 2 & 101.9 & 7.0 & 276 & 1.8 & 94.7 \\
$13 / 2$ & 2 & 24.6 & 17.0 & 318 & 0.7 & 27.5 \\
$15 / 1$ & 2 & 31.1 & 16.0 & 356 & 0.7 & 51.7 \\
$15 / 2$ & 2 & 16.7 & 19.5 & 582 & 0.5 & 37.8 \\
$16 / 1$ & 2 & 14.8 & 14.0 & 656 & 0.4 & 44.7 \\
$16 / 2$ & 2 & 9.7 & 19.5 & 608 & 0.3 & 35.0 \\
\hline
\end{tabular}

Tablo 2. Benzetim programina girilen linkler ve durakların güvenilirlikleri

\begin{tabular}{cccccc}
\hline & & \multicolumn{5}{c}{$\begin{array}{c}\text { Güvenilirlik } \\
\text { Hesabında } \\
\text { /Yön }\end{array}$} & $\begin{array}{c}\text { Şerit } \\
\text { Sayısı }\end{array}$ & $\begin{array}{c}\text { Durak } \\
\text { No }\end{array}$ & $\begin{array}{c}\text { Duraktalan } \\
\text { Duran Hat } \\
\text { Sayısı }\end{array}$ & $\begin{array}{c}\text { Güvenilirlik } \\
\text { Duruş Sayısı } \\
\text { (otobüs/ } \\
\text { gün) }\end{array}$ \\
\hline & & & \multicolumn{4}{c}{ (Bağıntı 3) } \\
\hline $1 / 1$ & 2 & 20145 & 3 & 135 & -0.758 \\
$1 / 2$ & 1 & 20144 & 3 & 137 & -0.517 \\
$3 / 1$ & 2 & 20147 & 3 & 135 & -0.779 \\
$3 / 2$ & 1 & 20146 & 3 & 137 & -0.490 \\
$4 / 2$ & 1 & 20148 & 3 & 137 & -0.475 \\
$5 / 1$ & 2 & 20151 & 3 & 135 & -0.827 \\
$5 / 2$ & 2 & 20001 & 2 & 29 & -0.547 \\
$5 / 2$ & 2 & 20002 & 1 & 27 & -0.348 \\
$5 / 2$ & 2 & 20003 & 2 & 39 & -0.405 \\
$5 / 2$ & 2 & 20004 & 2 & 32 & -0.332 \\
$5 / 2$ & 2 & 20005 & 1 & 46 & -0.372 \\
$5 / 2$ & 2 & 20007 & 1 & 27 & -0.173 \\
$5 / 2$ & 2 & 20008 & 3 & 76 & -0.159 \\
$5 / 2$ & 2 & 20152 & 3 & 137 & -0.425 \\
$7 / 1$ & 2 & 20153 & 15 & 715 & 0.711 \\
$7 / 2$ & 1 & 20154 & 15 & 438 & -0.313 \\
$8 / 1$ & 2 & 20155 & 15 & 715 & 0.563 \\
$8 / 1$ & 2 & 20157 & 15 & 715 & 0.524 \\
$8 / 2$ & 1 & 20158 & 15 & 439 & -0.279 \\
\hline & & & & &
\end{tabular}

\section{Güvenilirlik Değerlerinin Hesaplanması}

Çalışmada hatların her bir durağa varış sürelerinin elde edilebilmesi için İzmir'de kullanılan akıllı kart sistemine ait durak yoğunluk verilerinden yararlanılmıştır. Kentte ücret toplama amacıyla kullanılmakta olan akıllı kart sistemi, otobüslerin takip ettikleri güzergâh üzerinde bulunan duraklara geliş ve ayrılma süreleri ile otobüse binen yolcu sayılarını da kaydetmektedir. Çalışma kapsamında kullanılan verilerin veri tabanı ortamındaki görünümü ise Tablo 3'te sunulmuştur.

Akıllı kart sisteminde validatör ve GPS aygıtına sahip olan otobüsün konumu dinamik olarak her saniye belirlenebilmektedir. Sistem sürücü ve hat verilerini içeren sürücü kartının sefer başında okutulması ile aktif hale gelmektedir. Durak koordinatlarına belirli bir mesafe $(30 \mathrm{~m})$ yaklaşıldığı an durağa varış zamanı kaydedilmekte, otobüs 30 m'lik yarıçaptan çıktığı an ise ayrılış zamanı kaydedilmektedir. Yolculuk (servis) süresinin tamamının dikkate alınabilmesi için güvenilirlik ölçütleri hesaplanırken her bir durağa varış zamanı değerleri dikkate alınmıștır. Belirli bir hattın her bir seferinde duraklara varıș zamanlarına ait tanımlayıcı istatistikler kullanılarak birçok güvenilirlik ölçütü türetilebilmektedir. Liu ve Sinha [22] ve Chen ve ark. [1] yapmış oldukları çalışmalarda yolculuk süresi güvenilirliğini (RTi) Bağıntı 1 ile ifade etmektedir:

$$
R T_{i}=\frac{\mu_{t i}}{\sigma_{t i}}
$$

Burada; $\mu_{\mathrm{ti}} ;$ i. hatta incelenen otobüslerin yolculuk sürelerinin ortalaması, $\sigma_{\mathrm{ti}}$; i. hatta incelenen otobüslerin yolculuk sürelerinin standart sapmasidır.

$\mathrm{Bu}$ ölçütün, özellikle uzun mesafelerde hizmet veren, birçok sinyalize kavşağı kullanan, trafik gecikmesinin ve yolcu yükünün günden güne ve gün içerisindeki çeşitli zaman dilimlerinde düzensiz olarak değișim gösterdiği hatlar için uygun olabileceği vurgulanmaktadır [22]. Polus [6] ve Sterman ve Schofer [23] seyahat süresi güvenilirliğini, otobüslerin yolculuk süresine ait standart sapmanın tersi ile hesaplanabileceğini belirtmişlerdir:

$$
R T_{i}=\frac{1}{\sigma_{t i}}
$$


DEU FMD 21(61), 259-269, 2019

Tablo 3. Çalışma kapsamında kullanılan verilerin veri tabanı ortamındaki görünümü

\begin{tabular}{|c|c|c|c|c|c|c|c|c|c|c|}
\hline Yön & Hat no & Otobüs no & Plaka & Durak no & Durak adı & Sira no & $\begin{array}{c}\text { Varış } \\
\text { zamanı }\end{array}$ & $\begin{array}{c}\text { Ayrılış } \\
\text { zamanı }\end{array}$ & $\begin{array}{c}\text { Durakta kalma } \\
\text { süresi (dk) }\end{array}$ & $\begin{array}{l}\text { Binen } \\
\text { sayısı }\end{array}$ \\
\hline \multirow{10}{*}{ 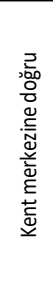 } & 126 & 16306 & DHB82 & 20707 & Cumhuriyet & 1 & 08:15:09 & 08:15:09 & 0 & \\
\hline & 126 & 16306 & DHB82 & 20706 & Saraç & 2 & $08: 15: 47$ & 08:15:47 & 0 & \\
\hline & 126 & 16306 & DHB82 & 20704 & Behçet Uz Lisesi & 3 & $08: 16: 35$ & $08: 16: 54$ & 0.32 & \\
\hline & 126 & 16306 & DHB82 & 20699 & Şair Eşref iöo & 4 & $08: 17: 10$ & $08: 17: 45$ & 0.58 & 3 \\
\hline & 126 & 16306 & DHB82 & 20698 & Surlar & 5 & $08: 17: 56$ & 08:18:37 & 0.68 & 4 \\
\hline & 126 & 16306 & DHB82 & 20696 & Bahçe & 6 & 08:19:03 & 08:19:46 & 0.72 & 6 \\
\hline & 126 & 16306 & DHB82 & 20688 & Daryol & 7 & $08: 20: 19$ & 08:20:34 & 0.25 & \\
\hline & 126 & 16306 & DHB82 & 20686 & Site & 8 & $08: 20: 47$ & 08:20:47 & 0 & \\
\hline & 126 & 16306 & DHB82 & 20684 & Atatürk iöo & 9 & $08: 21: 21$ & 08:21:52 & 0.52 & \\
\hline & 126 & 16306 & DHB82 & 20678 & Cumhuriyet M. & 10 & 08:22:49 & 08:23:04 & 0.25 & \\
\hline
\end{tabular}

Basitçe standart sapmanın tersi şeklinde olan ifade, ortalama değerden sapma büyüdükçe daha düşük güvenilirlik hesaplanmasını ifade etmektedir. Yolculuk süresinin tanımlayıcı istatistiklerine dayalı birçok temel formül, farklı normalizasyon yöntemleri ile birlikte (doğal logaritma vb.) çalışmada denenmiş, kullanılan bağımsız değişkenler ile en yüksek korelasyonu sağlayan güvenilirlik ifadesinin Polus [6] ve Sterman ve Schofer [23] tarafindan önerilen ölçütün doğal logaritmik dönüşümü olduğu belirlenmiştir:

$$
R T_{i}=\ln \left(\frac{1}{\sigma_{t i}}\right)
$$

Güvenilirlik ölçütü, üç aylık bir zaman periyodu boyunca (hafta sonu ve resmi tatiller hariç toplam 61 gün) duraktan geçen tüm analiz bölgesi hatları (26 hat) için hesaplanmıștır. Hesaplanan güvenilirlik değerlerine ait örnek grafik, 853 numaralı Egekent-Karşıyaka hattı için Şekil 7'de verilmiştir.

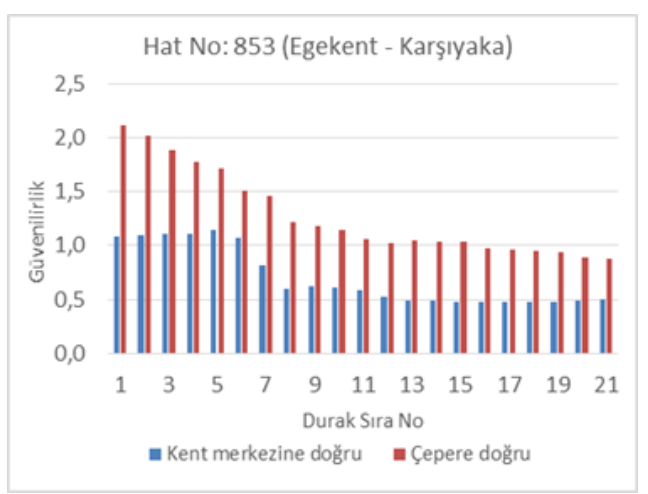

Şekil 7. Örnek bir hatta ait güvenilirlik değerleri

Sekilde görüldüğü gibi, otobüs seferi kent merkezine doğru yapıldığında, çepere doğru olan sefere kiyasla, güvenilirlik ortalama olarak \%50 daha düșük gerçekleșmektedir. Yalnızca ilk 1-7 durakları arasında, hattın başlangıç durakları kent merkezine uzak olduğundan, merkeze giden sefer için durak güvenilirlikleri çepere doğru olanlara daha yakındır.

\section{Güvenilirlik Tahmin Modeli}

Durak bazında hesaplanan güvenilirlik değerleri üzerinde etkili olan parametrelerin belirlenmesi amacıyla çoklu regresyon analizi yöntemi kullanılmıştır. Analizde güvenilirlik parametresi bağımlı değișken; durağın bulunduğu linke ait şerit sayısı, durakların bulunduğu kesitten geçen trafik hacmi; durağın bulunduğu linkin bağlandığı akım yukarı ve akım aşağı kavşaklardaki ortalama gecikme ve kuyruk uzunluğu değerleri; linke ait ortalama hiz ve ortalama yolculuk süreleri; durağı kullanan hat sayısı ve durakta duran günlük ortalama otobüs sayısı bağımsız değișken olarak tanımlanmıștır. Analizlerde, yukarıda tanımlanan bazı bağımsız değișkenlerin içsel bağımlı olabileceği göz önünde bulundurularak korelasyon analizi yapılmıştır. Elde edilen sonuçlar Tablo 4'te görülmektedir.

Tablo 4 incelendiğinde, beklenildiği gibi, gecikme ile ortalama hız, ortalama yolculuk süresi ve ortalama kuyruk uzunluğunun; ortalama hız ile ortalama yolculuk süresi ve ortalama kuyruk uzunluğunun; trafik hacmi ile ortalama kuyruk uzunluğunun; ortalama yolculuk süresi ile ortalama kuyruk uzunluğunun; durakta duran hat sayısı ile durakta duran otobüs sayısının, yüksek korelasyon katsayları ile içsel bağımlılık gösterdiği anlaşılmaktadır. Regresyon analizlerinde içsel bağımlılı̆̆ 0.3 'ten büyük parametreler bir arada kullanılmamıştır. Elde edilen model Bağıntı 4'te verilmiștir. 
Tablo 4. Korelasyon analizi sonuçları

\begin{tabular}{|c|c|c|c|c|c|c|c|}
\hline & $\begin{array}{r}\text { Gecikme } \\
\text { (sn/taştt) }\end{array}$ & $\begin{array}{l}\text { Ort. Hiz } \\
(\mathrm{km} / \mathrm{sa})\end{array}$ & $\begin{array}{c}\text { Trafik } \\
\text { Hacmi } \\
\text { (taşit/sa) } \\
\end{array}$ & $\begin{array}{l}\text { Ort. } \\
\text { Yolculuk } \\
\text { Süresi } \\
\text { (sn) }\end{array}$ & $\begin{array}{l}\text { Ort. } \\
\text { Kuyruk } \\
\text { Uzunluğu } \\
\text { (m) }\end{array}$ & $\begin{array}{c}\text { Durakta } \\
\text { Duran Hat } \\
\text { Sayısı }\end{array}$ & $\begin{array}{c}\text { Durakta } \\
\text { Duran } \\
\text { Otobüs } \\
\text { Sayvis } \\
\text { (otobüs/ } \\
\text { gün) }\end{array}$ \\
\hline $\begin{array}{l}\text { Gecikme } \\
\text { (sn/tassıtt) }\end{array}$ & 1 & & & & & & \\
\hline $\begin{array}{l}\text { Ort. Hiz } \\
(\mathrm{km} / \mathrm{sa})\end{array}$ & -0.422 & 1 & & & & & \\
\hline $\begin{array}{l}\text { Trafik Hacmi } \\
\text { (taşıtt/sa) }\end{array}$ & -0.071 & 0.135 & 1 & & & & \\
\hline $\begin{array}{l}\text { Ort. Yolculuk } \\
\text { süresi (sn) }\end{array}$ & 0.996 & -0.365 & -0.068 & 1 & & & \\
\hline $\begin{array}{l}\text { Ort. Kuyruk } \\
\text { Uzunluğu (m) }\end{array}$ & 0.517 & -0.607 & 0.341 & 0.465 & 1 & & \\
\hline $\begin{array}{l}\text { Durakta Duran } \\
\text { Hat Sayisı } \\
\text { Otobüs Sayisı }\end{array}$ & 0.090 & -0.004 & 0.214 & 0.101 & -0.006 & 1 & \\
\hline (otobüs/gün) & 0.063 & 0.060 & 0.261 & 0.076 & 0.006 & 0.937 & 1 \\
\hline
\end{tabular}

$R T=1.54 S S S-0.003 D D O+0.035 V$

Burada RT: yolculuk süresine bağlı güvenilirlik, SŞ: otobüsün geçtiği yol üzerindeki şerit sayısı, DDO: durakta duran otobüs sayısı (otobüs/gün), $\mathrm{V}$ : durağın üzerinde bulunduğu linke ait ortalama hı (km/saat) değerini ifade etmektedir. Bu ilişki, Bağıntı 3 ile hesaplanan güvenilirlik değerlerinin yol, trafik ve hat parametreleri kullanılarak tahmini sağlamaktadır. Böylece Bağıntı 3 için gerekli olan, tüm otobüslerin durağa ulaşım süresi istatistikleri yerine daha az ve elde edilmesi kolay veri ile güvenilirlik kestirilebilmekte, aynı zamanda daha yüksek güvenilirlik için hangi temel etkenlerin kontrol altında tutulması gerektiği anlaşılabilmektedir. Çoklu regresyon analizi ile elde edilen modelle ait istatistikler Tablo 5'te sunulmuștur.

Tablo 5. Üç bağımsız değișkenli çoklu regresyon analizi sonuçları

\begin{tabular}{lcccc}
\hline & $\beta$ & Standart Hata & t-ist & $p$ \\
\hline Şerit Sayısı & 1.538 & 0.191 & 8.04 & $1.31 * 10^{-11}$ \\
$\begin{array}{l}\text { Durakta duran } \\
\text { otobüs sayısı } \\
\text { (otobüs/gün) }\end{array}$ & -0.003 & $8.38 * 10^{-4}$ & -3.23 & $1.89 * 10^{-3}$ \\
$\begin{array}{l}\text { Ort. Hız } \\
\text { (km/saat) }\end{array}$ & 0.035 & 0.02 & 2.19 & 0.032 \\
\hline $\mathrm{R}^{2}: 0.862, \mathrm{~F}: 149.60, \mathrm{SS}: 1104.78, \mathrm{MS}: 368.26$ \\
\hline
\end{tabular}

İnceleme sonucunda bulunan "1"e yakın korelasyon katsayısı ve yüksek " $F$ " istatistiği, seçilen bağımsız değişkenlerin güvenilirliği tahmin etmede yeterli olduğunu göstermektedir. Modeldeki bağımlı değişkenlerin " $\mathrm{t}$ " istatistikleri incelendiğinde, șerit sayısının en etkili değișken olduğu görülmekte, bunu durakta duran otobüs sayısı ve ortalama hız izlemektedir. Şerit sayısının yüksek olması, otobüslerin trafik içindeki hareket kabiliyetini arttırıp duraklarda oluşabilecek otobüs kuyruklanmasını ve durağa yaklaşma/ayrılma sürelerini azaltabileceğinden, güvenilirliği birçok yönden yükseltebilen bir etkiye sahiptir.

İçsel bağımlılık açısından daha esnek davranılarak üst sınır 0.6 seçilirse ortalama kuyruk uzunluğu değişkeni de modele katılabilmektedir. Bu durumda ortaya çıkan çoklu regresyon sonuçları Tablo 6'da verilmiştir. İki modelin $\mathrm{t}$ istatistikleri karşılaştırıldığında, kuyruk uzunluğunun modele dahil edilmesinin şerit sayısının modeldeki etkisini azaltırken, ortalama hızın etkisini arttırdığı anlașılmaktadır. Alternatif modelin regresyon katsayısı 0.03 kadar daha yüksektir. Ortalama hız, her ne kadar bu çalışmada benzetim modeliyle elde edilmiş olsa da, basit saha gözlemleriyle de temin edilebilmektedir. Ortalama kuyruk uzunluğu için ise aynı şeyi söylemek mümkün değildir. Saha gözlemlerinden elde edilebilmesi için her bir kavşakta uzun zaman ve emek gerektiren gözlemlere ihtiyaç duyulacaktır. Bu yüzden 0.03'lük bir başarım artışı için güvenilirlik tahmin modeline kuyruk uzunluğunun ilave edilmesinin gerekliliği tartışmalı olup uygulamacılar tarafından takdir edilmelidir.

Tablo 6. Dört bağımsız değişkenli alternatif çoklu regresyon analizi sonuçları

\begin{tabular}{lcccc}
\hline & $\beta$ & $\begin{array}{c}\text { Standart } \\
\text { Hata }\end{array}$ & $\mathrm{t}$-ist & $\mathrm{p}$ \\
\hline Şerit sayısı & 1.048 & 0.205 & 5.11 & $2.62 * 10^{-6}$ \\
$\begin{array}{l}\text { Durakta duran } \\
\text { otobüs sayısı } \\
\text { (otobüs/gün) }\end{array}$ & -0.003 & $7.60 * 10^{-4}$ & -4.27 & $5.86 * 10^{-5}$ \\
$\begin{array}{l}\text { Ort. Hız } \\
\text { (km/saat) }\end{array}$ & 0.066 & 0.016 & 4.08 & $1.16 * 10^{-4}$ \\
$\begin{array}{l}\text { Ort. Kuyruk } \\
\text { uzunluğu (m) }\end{array}$ & -0.011 & 0.003 & -4.34 & $4.61 * 10^{-5}$ \\
\hline $\mathrm{R}^{2}: 0.891, \mathrm{~F}: 149.60, \mathrm{SS}: 1141.98, \mathrm{MS}: 285.49$ \\
\hline
\end{tabular}

\section{Tartışma ve Sonuç}

Özellikle gelișmekte olan ülkelerde șehirlerin sağlıklı ve sürdürülebilir gelişimini sağlamak için özel taşıt trafik artışının kontrol altına alınması, buna karşın hizmet düzeyi yüksek bir toplu taşıma sisteminin sağlanması gerekmektedir. Önceden belirlenmiş bir çizelgelemeye/zaman programına bağlllık durumunu ifade eden güvenilirlik, toplu ulaşım sisteminin hizmet düzeyini sayısal olarak ifade etmede kullanılabilecek basit ve karşılaştırılabilir bir ölçüttür. 
$\mathrm{Bu}$ çalıșmada kent içi otobüs hatlarına ait güvenilirliğin trafik ve yol geometrisine bağlı hangi parametrelerden etkilendiği ortaya konulmuştur. Böylece, otobüs hatlarının tasarımında, etkin trafik ve yol koşullarının güvenilir bir işletme sağlayıp sağlayamayacağı belirlenebilmektedir. Ayrıca otobüs güzergâhlarında planlanan değişiklikler, güzergâh hizmete alınmadan önce güvenilirlik bakımından sınanabilecektir.

Yapılan gözlem ve analizler sonucunda aşağıdaki sonuçlara ulaşılmıştır:

- Durakta duran otobüs sayısı arttıkça, durağın güvenilirliği azalmaktadır. Bunda, otobüs duraklarının indirme-bindirme yaptıkları alanının uzunluğu veya otobüs durak cebinin uzunluğu gibi faktörlerin de etkili olduğu söylenebilir. Durağa gelen otobüslerin bir kısmı, durak alanı içinde yolcu indiren/bindiren otobüsleri ve bu otobüslerin duraktan ayrılmak için harcadıkları süreyi de beklemek zorunda kaldığl düşünülürse bu durum güvenilirlik değerini düşmektedir.

-Linklere ait ortalama hız değerleri benzetim programından elde edilmiştir. Otobüs duraklarının bulunduğu linkler üzerinde hareket eden araçların ortalama hızları arttıkça, durakların güvenilirliği de artmaktadır. Böylece otobüsler, öngörülen yolculuk sürelerine uygun hızlarda hareket edebilmekte ve duraklara zamanında varabilmektedirler. Yol kesimlerindeki ortalama hızların arttırılması ancak, ağ yönetimi (sola dönüșlerin belirli kavşaklarda kısıtlanması, sinyal optimizasyonu, uyarlanabilir sinyal kontrolü vb.) ve talep yöntemi (özel taşıtlar için tıkanıklık ücretlendirmesi, zirve saat sınırlamaları vb.) gibi köklü ve kapsamlı önlemler ile mümkün olabilecektir.

-Otobüs duraklarının yer aldığı linklerdeki/arterlerdeki şerit sayılarının artması, durakların güvenilirliğini de arttırmaktadır. Otobüs güzergâhının kullandığı arterlerde, șerit sürekliliğinin sağlanması ve bu șeritlerin etkin kullanılması için yol kenarı ve/veya cepli parklanmaların önlenmesi gerekliliği ortaya çıkmaktadır.

Çalışmada kullanılan mikroskobik tabanlı benzetim programı, ölçülmesi oldukça güç olan gerçek gözlemlere gerek duyulmadan birçok trafik parametresinin elde edilmesini sağlamaktadır. İncelenen trafik parametreleri içinden kuyruk uzunluğu ve gecikme gibi daha mikroskobik ve dinamik olan parametreler yerine, ortalama hız ve șerit sayısı gibi daha statik ve kolay gözlemlenebilir parametrelerin güvenilirlik üzerinde etkili bulunması, modelin uygulamada kullanılabilirliğini arttırmaktadır. $\mathrm{Bu}$ veriler benzetim modeline ihtiyaç duyulmadan da elde edilebileceğinden, tahmin modelinin kullanılması için uygulamacıların benzetim yazılımına sahip olma zorunluluğu ortadan kalkmakta ve dolayısıyla güvenilirlik tahmin modeli bu formuyla daha yaygin bir etkiye sahip olmaktadır. Tahmin bașarımını \%3 mertebesinde arttıran ve elde edilmesi diğer verilere göre oldukça emek isteyen ortalama kuyruk uzunluğu verisinin modele dahil edilip edilmesi çok anlamlı görülmemekle beraber uygulamacıların tercihine bırakılmıștır.

İlerleyen çalıșmalarda, trafik ve güzergâh özelliklerinin yanı sıra, ișletme ve yolcu özellikleri ile iniş-biniş süresi gibi durak bazlı ve insan faktörü içeren gecikmelerin de güvenilirlik tahmin modellerine açıklayıcı değișken olarak ilave edilmesi gerektiği düşünülmektedir.

\section{Teşekkür}

$\mathrm{Bu}$ çalışma, TÜBITTAK tarafından desteklenen 112M117 no.lu ve "Akıllı Kart Verilerine Dayalı Güvenilirlik Ölçütlerinin Toplu Ulaşım Atama Modellerine Entegrasyonu" bașlıklı araștırma projesinde elde edilen bulguları içermektedir. Bu bağlamda, sağladığı proje desteği için TÜBITTAK'a ve veri temininde verdiği destek için İzmir Büyükșehir Belediyesi ESHOT Genel Müdürlügü'ne teşekkür ederiz.

\section{Kaynakça}

[1] Chen,X., Yu L., Zhang Y., Guo J. 2009. Analyzing Urban Bus Service Reliability at the Stop, Route, and Network Levels. Transportation Research Part A, Cilt:43, s. 722-734. DOI: 10.1016/j.tra.2009.07.006

[2] Turnquist, M. A., Bowman, L. A. 1980. The effects of network structure on reliability of transit service. Transportation Research, Cilt. 14(B), s. 79-86. DOI: 10.1016/ 0191-2615(80)90034-X

[3] Murat, Y. S., Uludağ, N. 2008. Bulanık mantık ve lojistik regresyon yöntemleri ile ulașım ağlarında rota seçim davranışının modellenmesi. Teknik Dergi, Cilt. 19(2), s. 4363-4379.

[4] Doğan, G., Özuysal M. 2017. Toplu ulaşımda bekleme süresini etkileyen faktörlerin incelenmesi: güvenilirlik, yolcu bilgilendirme sistemi ve fiziksel koșullar. Teknik Dergi, Cilt. 28 (3), s. 7927-7954. DOI: 10.18400/ tekderg.307513

[5] Kittelson \& Associates Inc., Urbitran Inc., LKC Consulting Services Inc., MORPACE International Inc., Queensland Uni. of Tech. and Nakanishi, Y. 2003. A guidebook for developing a transit performance 
DEU FMD 21(61), 259-269, 2019

measurement system. TCRP Report 88, Transportation Research Board, Washington, D.C.

[6] Polus, A. 1978. Modelling and measurements of bus service reliability. Transportation Research, Cilt. 12 s. 253-256. DOI:10.1016/0041-1647(78)90067-9.

[7] Bates, J., Polak, J., Jones, P., Cook, A. 2001. The valuation of reliability for personal travel. Transportation Research Part E, Cilt. 37, s. 191-229. DOI: 10.1016/S1366-5545(00)00011-9.

[8] Ceder A. 2007. Public Transit Planning and Operation. Elsevier, Oxford.

[9] Türk Standartları Enstitüsü, TS 6407 Şehir içi ulaşım hesaplamalarında, araç tiplerine göre kullanılacak oto birim katsayıları, Türk Standardı, TS 6407, Ankara, 2013.

[10] Aimsun 2017. Aimsun new features. https://www.aimsun.com/aimsun (Erişim Tarihi: 15.09.2017)

[11] Cakıcı, Z., Murat, Y.S. 2016. Sinyalize dönel kavşaklar için hesap yöntemi önerisi ve performans analizi. Teknik Dergi, Cilt. 27(4), s. 7569-7592.

[12] Nassırı, H., Tabatabaie, S., Sahebı, S. 2017. Delaybased passenger car equivalent at signalized intersections in Iran. Promet Traffic \& Transportation, Cilt. 29(2), s. 135-142. DOI: 10.7307/ptt.v29i2.2040

[13] Chaudhry, M.S., Ranjitkar, P. 2009. Capacity analysis of signalised intersection using microsimulation. 32nd Australian Transport Research Forum, Auckland, New Zealand.

[14] Alex, S., Isaac, K. P. 2015. Dynamic PCU values at signalised intersections in India for mixed traffic. International Journal for Traffic and Transport Engineering, Cilt. 5(2), s. 197 - 209. DOI: 10.7708/ijtte.2015.5(2).09

[15] Lu, X., Lee, J., Chen, D., Bared, J., Dailey, D., Shladover, S. E. 2014. Freeway micro-simulation calibration: Case study using Aimsun and Vissim with detailed field data. 93rd TRB Annual Meeting, Jan. 12-16. Washington D.C.

[16] ITE (Institute of Transportation Engineers) 1994. Determinining Vehicle Signal Change and Clearance Intervals. Publication IR-073. An Informational Report of the Institute of Transportation Engineers (ITE), Washington, DC., 12p.

[17] Akçelik, R., Besley, M., Roper, R. 1999. Fundamental Relationships for Traffic Flows at Signalised Intersections. Research Report ARR 340. ARRB Transport Research Ltd., Vermont South, Australia.

[18] Clement, S. J., Taylor, M. A. P., Yue, W. L. 2004. Simple platoon advancement: a model of automated vehicle movement at signalized intersections, Transportation Research Part C: Emerging Technologies, Cilt. 12(3-4), s. 293-320. DOI: 10.1016/j.trc.2004.07.012

[19] Bonneson, J. A. 1992. Modeling queued driver behavior at signalized junctions, Transportation Research Record: Journal of Transportation Research Board 1365: 99-107

[20] Tanyel, S., Çalışkanelli, S. P., Koyuncu, M. Alver, Y., Murat, Y. Ș. 2014. Kentiçi yol kesimlerindeki sürücü davranışlarının kapasite ve kavşak başarım üzerindeki etkisinin araştırılması. TÜBITTAK MFAG Proje 110M677, 1-309.

[21] DPTI (Department of Planning, Transportation and Infrastructure) 2013. Government of South
Australia, Aimsun Traffic Simulation Model Development Manual, October.

[22] Liu, R., Sinha, S. 2007. Modelling urban bus service and passenger reliability. The Third International Symposium on Transportation Network Reliability (INSTR), Hague, Netherlands.

[23] Sterman, B. P., Schofer, J. L. 1976. Factors affecting reliability of urban bus services. Transport Engineering Journal, s.147-159. 